\title{
INTRAVENOUS CLARITHROMYCIN: A VALUABLE IMMUNOMODULATOR FOR SEVERE INFECTIONS
}

\author{
Leventogiannis Konstantinos, Giamarellos-Bourboulis J. Evangelos
}

$4^{\text {th }}$ Department of Internal Medicine, University of Athens, Medical School, Greece

Primljen/Received 09. 03. 2014. god.

Abstract: There are many studies suggesting that intake of a macrolide in the treatment regimen is linked with improved outcomes for patients with community-acquired pneumonia. However this was never proved through one randomized clinical study (RCT). We reviewed all pre-clinical and clinical development from 2003 to 2014 for intravenous clarithromycin as adjunctive treatment of severe infections. This process ended with the conduct of two RCTs; the first in 200 patients with ventilator-associated pneumonia; and the second in 600 patients with proven or suspected Gram-negative infections of non-pulmonary origin. The two RCTs has similar findings; significant decrease of mortality of patients with septic shock and multiple organ dysfunctions; and shorter resolution of severe infections. The second RCT also showed significant savings for survivors. These data support the use of intravenous clarithromycin as adjunctive treatment of severe infections.

Key words: clarithromycin, cytokines, inflammation, sepsis

\section{INTRODUCTION}

Despite increasing antimicrobial resistance, intake of a macrolide is connected with improved outcomes of patients with community-acquired pneumonia (CAP) (1-5). Benefit is even pronounced among patients with bacteremia by macrolide-resistant Streptococcus pneumonia (5) leading people to consider that this comes from modulation of the immune response of the host by macrolides. However, the definite proof may come only from randomized clinical trials (RCTs). No RCT has ever been conducted to prove benefit of macrolides intake in the outcome of severe CAP. Despite the lack of such RCT, the updated Surviving Sepsis Campaign guidelines recommend the use of a macrolide for the management of CAP complica-
Prihvaćen/Accepted 02. 04. 2014. god.

ted by bacteremia from Streptococcus pneumoniae (6), giving emphasis to the validity of this intervention.

Our group has launched a research program since 2003 to explore the modulation of the immune response of the host and the benefit that is shown for patients with severe infections when intravenous clarithromycin is added in the treatment regimen. The present review outlines the main findings of these research efforts.

\section{ANIMAL STUDIES}

The efficacy of intravenously administered clarithromycin was studied in a series of pre-clinical animal studies. Results of these studies are summarized in Table 1 (7-11). The main infection models studied were pyelonephritis, pleuritis and peritonitis after cecal ligation and puncture. For pyelonephritis and pleuritis bacterial challenge was done by multidrug- and pandrug-resistant isolates of Pseudomonas aeruginosa and Klebsiella pneumonia against which macrolide do not possess any antimicrobial activity. Results from these animal studies revealed that clarithromycin, either alone or in co-administration with amikacin, prolonged survival considerably. This was accompanied by improvement in oxygen saturation and heart rate when administered in rabbits when signs of pulmonary edema appear (10). In pyelonephritis by multidrug-resistant P.aeruginosa and pandrug-resistant K.pneumoniae, histology showed that clarithromycin attenuated: a) peribronchial inflammation in the lung; b) mononuclear infiltration and necrosis in the liver and kidney; and c) activation of B- and T-cell rich areas in spleen $(10,11)$. The common denominator of all these studies was that monocytes and lymphocytes appeared to be the main target of action of clarithromycin.

In one model of pleuritis induced by multidrug-resistant P.aeruginosa, specimens of pleural fluid of rab- 
Table 1. Summary of pre-clinical studies assessing the efficacy of intravenous clarithromycin in acute infection models

\begin{tabular}{|c|c|c|c|c|c|c|c|}
\hline Reference & $\begin{array}{l}\text { Experimental } \\
\text { model }\end{array}$ & Microorganism & Survival & $\begin{array}{l}\text { Bacterial } \\
\text { growth }\end{array}$ & $\begin{array}{l}\text { Circulating } \\
\text { mediators }\end{array}$ & Mononuclears & Histology \\
\hline 7 & Pyelonephritis & $\begin{array}{l}\text { MDR Pseudomonas } \\
\text { aeruginosa }\end{array}$ & $\begin{array}{l}\text { Prolongation when } \\
\text { co-administrated with } \\
\text { amikacin }\end{array}$ & No effect & $\begin{array}{l}\downarrow \text { TNF } \alpha, \\
\text { MDA }\end{array}$ & N/A & $\mathrm{N} / \mathrm{A}$ \\
\hline 8 & Pyelonephritis & $\begin{array}{l}\text { Susceptible } \\
\text { Escherichia coli }\end{array}$ & $\begin{array}{l}\text { Prolongation as } \\
\text { pretreatment and } \\
\text { treatment }\end{array}$ & No effect & $\begin{array}{l}\downarrow \text { TNF } \alpha, \\
\text { MDA }\end{array}$ & $\begin{array}{l}\downarrow \text { monocytic } \\
\text { caspase-3 }\end{array}$ & N/A \\
\hline 9 & Pyelonephritis & $\begin{array}{l}\text { Susceptible } \\
\text { Escherichia coli }\end{array}$ & $\begin{array}{l}\text { Prolongation when } \\
\text { co-administered with } \\
\text { amikacin at signs of } \\
\text { sepsis }\end{array}$ & No effect & No effect & $\mathrm{N} / \mathrm{A}$ & $\mathrm{N} / \mathrm{A}$ \\
\hline 10 & Pyelonephritis & $\begin{array}{l}\text { MDR Pseudomonas } \\
\text { aeruginosa }\end{array}$ & $\begin{array}{l}\text { Prolongation when } \\
\text { co-administrated with } \\
\text { amikacin at signs of } \\
\text { sepsis }\end{array}$ & No effect & No effect & $\begin{array}{l}\downarrow \text { ex vivo } \\
\text { production of } \\
\text { TNF } \alpha \text { by } \\
\text { monocytes }\end{array}$ & $\begin{array}{l}\downarrow \text { lung-spleen } \\
\text { inflammation }\end{array}$ \\
\hline 11 & Pyelonephritis & $\begin{array}{l}\text { PDR } \\
\text { Klebsiellapneumoniae }\end{array}$ & $\mathrm{N} / \mathrm{A}$ & No effect & $\begin{array}{l}\downarrow \text { TNF } \alpha \\
\text { MDA }\end{array}$ & $\begin{array}{l}\downarrow \text { ex vivo } \\
\text { production of } \\
\text { TNF } \alpha \text { by } \\
\text { monocytes }\end{array}$ & $\begin{array}{l}\downarrow \text { kidney-liver } \\
\text { inflammation }\end{array}$ \\
\hline 12 & $\begin{array}{l}\text { Peritonitis by } \\
\text { CLP }\end{array}$ & & $\begin{array}{l}\text { Prolongation when } \\
\text { co-administrated } \\
\text { with piperacillin/ } \\
\text { /tazobactam }\end{array}$ & No effect & N/A & $\begin{array}{l}\downarrow \text { ex vivo } \\
\text { production } \\
\text { of TNF } \alpha \text {, } \\
\downarrow \text { apoptosis } \\
\text { lymphocytes } \\
\text { and monocytes }\end{array}$ & $\mathrm{N} / \mathrm{A}$ \\
\hline 13 & Pleuritis & $\begin{array}{l}\text { MDR Pseudomonas } \\
\text { aeruginosa }\end{array}$ & $\mathrm{N} / \mathrm{A}$ & $\begin{array}{l}\downarrow \text { lung and } \\
\text { pleural } \\
\text { fluid }\end{array}$ & $\downarrow \mathrm{TNF} \alpha$ & $\begin{array}{l}\downarrow \text { production } \\
\text { of TNF } \alpha \text { and } \\
\text { IL-6 }\end{array}$ & \\
\hline
\end{tabular}

Abbreviations: CLP: cecal ligation and puncture; IL: interleukin; MDA: malondialdehyde; MDR: multidrug-resistant; N/A: not assessed; PDR: pandrug-resistant, TNF $\alpha$ : tumor necrosis factor-alpha ; $\downarrow$ : decrease

bits were used to stimulate cytokine production from U937 monocytes. It was shown that those specimens coming from animals treated with a combination of clarithromycin and piperacillin/tazobactam produced much lower concentrations of tumour necrosis factor-alpha (TNF $\alpha$ ) and of interleukin (IL)-6 compared with the amount of cytokines released from specimens coming from rabbits administered single piperacillin/tazobactam (13). This finding drives the hypothesis that part of the mode of action of clarithromycin is mediated through attenuated release of pathogen-associated molecular patterns by P.aeruginosa .

\section{INTRAVENOUS CLARITHROMYCIN IN SEPSIS: CLINICAL EVIDENCE}

The promising results of experimental studies led us to design and conduct two randomized clinical trials to explore the immunomodulatory effect of clarithromycin in patients with sepsis. It is suggested that part of the failure of previous clinical trials with immunomodulators was due to the inclusion of heterogenous groups of patients, namely patients with sepsis caused by different types of infections. To overcome this, the first trial enrolled patients suffering from the same underlying infection, namely ventilator-associated pneumonia (VAP). Two hundred patients with sepsis and VAP were enrolled in a double-blind, randomized, multicenter trial from June 2004 until November 2005 (14). Clarithromycin ( $1 \mathrm{~g})$ was administered intravenously once daily for 3 consecutive days in 100 patients; another 100 patients were treated with placebo. Main outcomes were resolution of VAP, duration of mechanical ventilation, and sepsis-related mortality within 28 days. There were no differences between groups in baseline characteristics. Microbiology was also assessed 
and Gram-negative bacteria growing at counts greater than $10^{5} \mathrm{cfu} / \mathrm{ml}$ of tracheobronchial secretions (TBS) were considered. Gram-negative bacteria were identified as underlying pathogens in 68 placebo-treated and 66 clarithromycin-treated patients. The most frequent pathogens were Acinetobacter baumanniiin 43 and 36 patients and P.aeruginosa in 12 and 17 patients. Initial empirical antimicrobial coverage was appropriate against $62.7 \%$ of pathogens isolated from placebo-treated patients and against $75.4 \%$ of pathogens isolated from clarithromycin-treated patients $(\mathrm{p}=0.44$ between groups). TBS were sampled again at follow-up. Eradication of the pathogen was achieved in $25.4 \%$ and $33.8 \%$ of cases on day $5(\mathrm{p}=0.31$ between groups) and in $31.3 \%$ and $29.2 \%$ of cases on day $10(\mathrm{p}=0.82$ between groups). Sepsis-related mortality was $25 \%$ in the placebo group and $23.3 \%$ in the clarithromycin group. Odds ratio for death from septic shock and multiple organ failure was 19.00 in placebo-treated patients; it was reduced to 3.78 in clarithromycin treated patients ( $p=0.043$ between groups). VAP resolved in $72.2 \%$ of survivors treated with placebo and in $79.9 \%$ of survivors treated with clarithromycin. Median time to resolution of VAP was 15.5 days in the placebo group and 10.0 days in the clarithromycin group scores $(\mathrm{p}=$ 0.011). Mean clinical pulmonary infection score for the placebo and the clarithromycin group on study enrolment were 7.92 and 7.62 , respectively $(p=0.29)$. It was decreased to 6.10 and 5.23 respectively on day 5 of follow-up ( $\mathrm{p}=0.016)$; and to 5.88 and 5.09 respectively on day 10 of follow-up $(\mathrm{p}=0.032)$. Weaning from mechanical ventilation was performed in $58.6 \%$ of placebo-treated patients within a median period of 22.5 days, and in $72.5 \%$ of clarithromycin treated patients within a median period of 16.0 days $(p=0.049)$.

To confirm these findings in another patient population, a second RCT was conducted in 600 patients with proved or suspected Gram-negative infections i.e. primary Gram-negative bacteremia, acute pyelonephritis and acute intrabdominal infections aggravated by systemic inflammatory response syndrome (15). Clarithromycin blind treatment was assigned to 302 patients; 298 patients were treated with placebo. In this $\mathrm{RCT}$, period of treatment was prolonged from three to four days. The primary endpoint was mortality by severe sepsis/shock and MODS; resolution of infection and hospitalization costs were the secondary endpoints. Demographics and sepsis severity were similar between groups. The most common pathogens were Gram-negative bacteria namely E.coli $(36.2 \%$ of bloodstream pathogens in the placebo arm and $43.8 \%$ of bloodstream pathogens in the clarithromycin arm), K.pneumoniae $(21.2 \%$ and $11.2 \%$ respectively), P.aeruginosa (10.0\% and 6.7\% respectively) and A.ba- umannii (11.2\% and 6.7\% respectively). The time from sepsis onset to start of antimicrobials and appropriateness of antimicrobials did not differ between groups.

Overall 28-day mortality was similar between groups being $17.1 \%$ in the placebo group and $18.5 \%$ in the clarithromycin group. Mortality of placebo-treated patients with septic shock and MODS was $73.1 \%$ compared to $53.6 \%$ of clarithromycin-treated patients $(\mathrm{p}=$ $0.020)$. The median time until resolution of infection was 10 days among patients with severe sepsis/shock treated with placebo and 6 days among patients with severe sepsis/shock treated with clarithromycin $(\mathrm{p}=$ 0.037 ). The median cost of hospitalization was $€ 3383.5$ for survivors of the placebo arm and $€ 2269$.3 for survivors of the clarithromycin arm $(\mathrm{p}=0.044)$. Serious adverse events were observed in $1.3 \%$ and $0.7 \%$ of placebo- and clarithromycin-treated patients, respectively $(\mathrm{p}=0.502)$.

The findings of the second trial fully confirm results of the first trial. Intervention with clarithromycin decreased mortality by septic shock and MODS and shortened the time until resolution of Gram-negative infections worsened by severe sepsis or septic shock. As expected, earlier resolution of severe Gram-negative infections was accompanied by significant savings for survivors. More precisely, median savings for every survivor were $€ 1114.3$. The studied intervention costs $€ 70$ per patient.

\section{WHAT IS THE MECHANISM OF ACTION OF MACROLIDES?}

It is traditionally conceived that macrolides attenuate the inflammatory response of the host. Most of conducted studies in animals including those used for the pre-clinical development of intravenous clarithromycin in sepsis support this concept. Our animal studies indicate that treatment with intravenous clarithromycin leads to decreased circulating levels of pro-inflammatory mediators and to attenuation of the mononucleat tissue infiltrates (Table 1). To the same end, studies of infected mice show that pre-treatment with azithromycin is accompanied by decreased concentrations of pro-inflammatory cytokines in the systemic circulation and in the lung $(16,17,18)$. It is well-known that macrolides attenuate pro-inflammatory phenomena in the lung where they accumulate. These properties may well explain the benefit shown in patients with VAP of the first RCT but not in patients of the second RCT who were not sufferers from any lung infection.

To explore the effect of intravenous clarithromycin in the inflammatory cascade in the first trial of patients with VAP (19), circulating cytokines were 
measured before allocation to blind treatment and for six consecutive days. On the same time intervals, circulating monocytes were isolated and stimulated for cytokine production. Expression of the co-stimulatory molecule CD86 involved in antigen presentation was also measured on the cell membranes of monocytes. Contrary to what was expected, the ratio of circulating IL-10 to TNF $\alpha$ was decreased on day 4 in the clarithromycin arm compared to the placebo arm. On this same day, expression of CD86 on monocytes was increased as was also their ability for the production of IL-6 after stimulation with bacterial ligands. These findings were much pronounced among patients with septic shock and MODS for whom most of survival benefit was shown. This tight time connection between treatment and effect may indicate that clarithromycin is a modulator of the biological function of monocytes so as to corroborate animal studies. However these findings also suggest that in the clinical field intravenous clarithromycin modulated the function of monocytes towards reversal of sepsis-induced immunoparalysis of patients. The ratio of pro-inflammatory to anti-inflammatory cytokines was restored, antigen-presentation was more efficient and monocytes became fully functional for the production of pro-inflammatory cytokines.

It is now widely recognized that when severe sepsis and MODS develop, the host has entered into a state of immunoparalysis (20). The key components of sepsis-induced immunoparalysis are failure of monocytes for adequate cytokine production after stimulation and defective antigen presentation. These defects were fully restored in patients with VAP treated with clarithromycin particularly those with septic shock and MODS.

\section{CONCLUSIONS}

Despite the existence of many retrospective analysis showing improved outcome of severe CAP when a macrolide is added to the treatment regimen of CAP, no RCT is available to definitively prove this benefit. Despite the lack of such RCT, the updated Surviving Sepsis Campaign guidelines recommend the use of a macrolide for the management of CAP complicated by bacteremia from Streptococcus pneumoniae. The only available RCTs in critically ill patients compare the efficacy of intravenous clarithromycin over placebo when added to the standard of care of ventilator-associated pneumonia and of Gram-negative infections of non-pulmonary origin. Common findings of both RCTs are decrease of mortality and earlier resolution of infection of the most severe patients. These findings definitively support a novel therapeutic indication of intravenous clarithromycin for the severely ill patients.
Abbreviations
CAP - community-acquired pneumonia
IL - interleukin
MODS - multiple organ dysfunction syndrome
RCT - randomized clinical trial
TNF $\alpha$ - tumour necrosis factor-alpha
VAP - ventilator-associated pneumonia

\title{
Sažetak
}

\section{INTRAVENSKA PRIMENA CLARITHROMYCIN-A: DRAGOCEN IMUNOMODULATOR KOD TEŠKIH INFEKCIJA}

\author{
Leventogiannis Konstantinos, Giamarellos-Bourboulis J. Evangelos \\ $4^{\text {th }}$ Department of Internal Medicine, University of Athens, Medical School, Greece
}

Postoji mnogo studija koje sugerišu da je primena makrolida u lečenju upale pluća povezana sa boljim ishodom. Ipak, ovo nije nikada dokazano kroz jednu randomiziranu kliničku studiju. Pregledali smo sve prekliničke i kliničke rezultate od 2003. do 2014. godine, vezane za intravensku primenu klaritromicina kao dodatnog lečenja teskih infekcija. Ovaj proces se završio sprovođenjem dve randomizirane kliničke studije; prva je uključila 200 pacijenata na mehaničkoj ventilaciji, sa upalom pluća; druga je uključila 600 pacijenata sa dokazanom ili sumnjivom Gram-negativnom infekcijom koja nema plucno poreklo. Dve randomizirane kliničke studije su imale slične rezultate; značajno povećanje mortaliteta pacijenata sa septičkim šokom i multiorganskom disfunkcijom; i kraće lečenje teških infekcija. Druga randomizirana klinička studija je pokazala značajnu uštedu za preživele. Ovi podaci podržavaju intravensku primenu klaritromicina kao dodatno lečenje teških infekcija.

Ključne reci: klaritromicin, citokini, upala, sepsa. 


\section{REFERENCES}

1. Lodise TP, Kwa A, Cosler L, Gupta R, Smith RP. Comparison of beta-lactam and macrolide combination therapy versus fluoroquinolone monotherapy in hospitalized Veterans Affairs patients with community-acquired pneumonia. Antimicrob Agents Chemother. 2007; 51(11): 3977-82.

2. Martinez JA, Horcajada JP, Almela M, et al. Addition of a macrolide to a beta-lactam-based empirical antibiotic regimen is associated with lower in-hospital mortality for patients with bacteremic pneumococcal pneumonia. Clin Infect Dis. 2003; 36(4): 389-95.

3. Garcia Vazquez E, Mensa J, Martinez JA, et al. Lower mortality among patients with community-acquired pneumonia treated with a macrolide plus a beta-lactam agent versus a beta-lactam agent alone. Eur J Clin Microbiol Infect Dis. 2005; 24(3): 190-5.

4. Metersky ML, Ma A, Houck PM, Bratzler DW. Antibiotics for bacteremic pneumonia: Improved outcomes with macrolides but not fluoroquinolones. Chest. 2007; 131(2): 466-73.

5. Restrepo MI, Mortensen EM, Waterer GW, Wunderink RG, Coalson JJ, Anzueto A. Impact of macrolide therapy on mortality for patients with severe sepsis due to pneumonia. Eur Respir J. 2009; 33(1): 153-9.

6. Dellinger RP, Levy MM, Rhodes A, et al. Surviving sepsis campaign: international guidelines for management of severe sepsis and septic shock. 2012. Crit Care Med. 2013; 41(2): 580-637.

7. Giamarellos-Bourboulis EJ, Adamis T, Laoutaris G, et al. Immunomodulatory clarithromycin treatment of experimental sepsis and acute pyelonephritis caused by multidrug-resistant Pseudomonas aeruginosa. Antimicrob Agents Chemother. 2004; 48(1): 93-9.

8. Giamarellos-Bourboulis E, Adamis T, Sabracos L, et al. Clarithromycin: immunomodulatory therapy of experimental sepsis and acute pyelonephritis by Escherichia coli. Scand J Infect Dis. 2005; 37(1): 48-54.

9. Giamarellos-Bourboulis EJ, Baziaka F, Antonopoulou A, et al. Clarithromycin co-administered with amikacin attenuates systemic inflammation in experimental sepsis with Escherichia coli. Int J Antimicrob Agents. 2005; 25(2): 168-72.

10. Giamarellos-Bourboulis EJ, Antonopoulou A, Raftogiannis $\mathrm{M}$, et al. Clarithromycin is an effective immunomodula- tor when administered late in experimental pyelonephritis by multidrug-resistant Pseudomonas aeruginosa. BMC Infect Dis. 2006; 6(1):31.

11. Giamarellos-Bourboulis EJ, Tziortzioti V, Koutoukas $\mathrm{P}$, et al. Clarithromycin is an effective immunomodulator in experimental pyelonephritis caused by pan-resistant Klebsiella pneumoniae. J Antimicrob Chemother. 2006; 57(5): 937-44.

12. Atmatzidis S, Koutelidakis I, Chatzimavroudis G, et al. Clarithromycin modulates immune responses in experimental peritonitis. Int J Antimicrob Agents. 2011; 37(4): 347-51.

13. Tsovolou EC, Tzepi IM, Spyridaki A, et al. Effect of clarithromycin in experimental empyema by multidrug-resistant Pseudomonas aeruginosa. APMIS. 2014; 122(1): 68-75.

14. Giamarellos-Bourboulis EJ, Pechere JC, Routsi C, et al. Effect of clarithromycin in patients with sepsis and ventilator-associated pneumonia. Clin Infect Dis. 2008; 46(8): 1157-64.

15. Giamarellos-Bourboulis EJ, Mylona V, Antonopoulou A, et al. Effect of clarithromycin in patients with suspected Gram-negative sepsis: results of a randomized controlled trial. J Antimicrob. Chemother. 2014; 69(4): 1111-8.

16. Bosnar M, Bosnjak B, Cuzic S, et al. Azithromycin and clarithromycin inhibit lipopolysaccharide-induced murine pulmonary neutrophilia mainly through effects on macrophage-derived granulocyte-macrophage colony-stimulating factor and interleukin-1beta. J Pharmacol Exp Ther. 2009; 331(1): 104-13.

17. Shinkai M, Henke MO, Rubin BK. Macrolide antibiotics as immunomodulatory medications: proposed mechanisms of action. PharmacolTher. 2008; 117(3): 393-405.

18. Yamada K, Yanagihara K, Kaku N, et al. Azithromycin attenuates lung inflammation in a mouse model of ventilator-associated pneumonia by multidrug-resistant Acinetobacterbaumannii. Antimicrob Agents Chemother. 2013; 57: 3883-8.

19. Spyridaki A, Raftogiannis M, Antonopoulou A, et al. Effect of clarithromycin in inflammatory markers of patients with ventilator-associated pneumonia and sepsis caused by Gram-negative bacteria: results from a randomized clinical study. Antimicrob Agents Chemother. 2012; 56(7): 3819-25.

20. Boomer JS, To K, Chang KC, et al. Immunosuppression in patients who die of sepsis and multiple organ failure. JAMA. 2011; 306(23): 2594-605.

\section{Correspondence to/Autor za korespondenciju}

Evangelos J. Giamarellos-Bourboulis, MD, PhD

$4^{\text {th }}$ Department of Internal Medicine

ATTIKON University Hospital

1 Rimini Str,

12462, Athens, Greece

Tel: +30 2105831994

Fax: +302105326446

Email: egiamarel@med.uoa.gr 
